\title{
STUDI EFEKTIFITAS PENGGUNAAN TUNED MASS DAMPER UNTUK MENGURANGI PENGARUH BEBAN GEMPA PADA STRUKTUR BANGUNAN TINGGI DENGAN LAYOUT BANGUNAN BERBENTUK "U"
}

\author{
Jati Sunaryati ${ }^{1}$, Rudy Ferial ${ }^{2}$, Dicky Febri Hadi ${ }^{3}$
}

\begin{abstract}
ABSTRAK
Redaman adalah fenomena yang ada dalam setiap struktur, fenomena tersebut dapat mengurangi getaran yang disebabkan oleh kekuatan eksternal untuk diterapkan sistem struktur. Berbagai jenis peredam telah dikenal dewasa ini, salah satunya adalah Tuned Mass Damper (TMD) dimana sistem ini menerapkan konsep kontrol pada struktur. Tulisan ini menyajikan studi efektifitas TMD yang dipasang pada struktur gedung bangunan tinggi. Pemasangan TMD pada struktur biasanya adalah pada bangunan-bangunan tinggi dengan layout berbentuk bujursangkar. Oleh karena itu dalam tulisan ini akan dikaji efektifitas pemakaian $T M D$ bila digunakan pada bangunan tinggi dengan layout berbentuk " $\mathrm{U}$ ". Respons struktur yang pelajari adalah gaya dalam, deformasi dan perioda dari struktur tanpa dan dengan $T M D$ pada bangunan 40 lantai. Massa $T M D$ ditetapkan sebesar 1\%, $2 \%$, dan 3\% dari massa struktur utamanya. Tipe TMD dibagi 2 (dua), terdiri dari 1 TMD (Single $T M D)$ dan 2 TMD (Multi TMD) yang diletakkan di lantai paling atas bangunan gedung. Hasil studi menunjukkan bahwa umumnya respons struktur dapat teredam oleh TMD dan penggunaan Single TMD lebih efektif dari pada Multi TMD pada bangunan tinggi dengan layout bangunan berbentuk "U".
\end{abstract}

Kata Kunci : redaman, bangunan tinggi, $T M D$, beban gempa, deformasi, perioda.

\section{PENDAHULUAN}

Gempa merupakan salah satu beban yang dapat menyebabkan kerusakan pada struktur. Sementara itu, Indonesia merupakan daerah rawan gempa sehingga menuntut perlunya pertimbangan untuk membangun struktur bangunan yang tahan dan adaptif terhadap beban gempa. Oleh sebab itu, evaluasi total kinerja struktur bangunan sangat penting untuk dilakukan.

Pada bangunan tinggi, umumnya akan mengalami perpindahan horizontal (swaying) akibat beban gempa dan beban angin. Tetapi pada bangunan tinggi sistem konvensional, terjadi efek kunci terhadap gerakan lateral akibat gaya gravitasi yang besar, karena sistem struktur menggunakan material yang berat, sehingga pengaruh swaying dapat diredam. Inovasi teknologi struktur bangunan tinggi dan teknologi bahan cenderung untuk membuat material yang semakin ringan, maka beban gempa dan beban angin pada bangunan pencakar langit modern menjadi faktor yang harus dipertimbangkan.

Salah satu cara untuk mengatasi permasalahan ini adalah dengan menerapkan teknologi kontrol pada struktur. Berdasarkan perlu tidaknya energi untuk menghasilkan gaya kontrol, sistem kontrol pada struktur dibagi atas dua jenis yaitu kontrol aktif dan kontrol pasif. Kontrol aktif memerlukan energi listrik untuk mengoperasikan alat dan menghasilkan gaya kontrol, sedangkan kontrol pasif memakai energi potensial yang dihasilkan dari respon struktur untuk menghasilkan gaya kontrol.

\footnotetext{
${ }^{1}$ Staf Pengajar Jurusan Teknik Sipil Fakultas Teknik Universitas Andalas, e-mail: jati@ft.unand.ac.id

${ }^{2}$ Staf Pengajar Jurusan Teknik Sipil Fakultas Teknik Universitas Andalas

${ }^{3}$ Mahasiswa Jurusan Teknik Sipil Fakultas Teknik Universitas Andalas
} 
Kelebihan kontrol aktif adalah karakteristik dinamik struktur dapat beradaptasi dengan beban dinamik yang timbul, sedangkan kelebihan kontrol pasif adalah karena kesederhanaan dalam desain, pemasangan, dan terutama pemeliharaannya.

Salah satu alat kontrol pasif pada struktur yaitu kontrol yang berdasarkan penggunaan massa tambahan sebagai sistem penyerap energi yang biasa disebut dengan Tuned Mass Damper (TMD). Tujuan utama pemasangan TMD pada gedung tinggi adalah untuk mengurangi goyangan yang berlebihan akibat beban angin dan menetralisir getaran akibat beban gempa. Diharapkan respons dinamik dari gedung dengan TMD akan menjadi lebih kecil bila struktur tersebut menerima gaya dinamik berupa angin maupun gempa.

\section{TUNED MASS DAMPER (TMD)}

Redaman adalah fenomena yang ada dalam setiap struktur. Nilai redaman pada struktur akan berhubungan dengan elemen apa dan bagaimana mereka berkumpul satu sama lain dalam sistem struktur. Berbagai jenis peredam telah dikenal sehubungan dengan fungsi mereka, yaitu peredam pasif dan aktif. Di bidang peredam pasif, salah satunya adalah TMD (Tuned Mass Damper).

Ide dasar TMD dijelaskan secara teoritis oleh Den Hartog. Andaikan terdapat suatu sistem massapegas menerima gaya harmonis, lalu kepada sistem itu ditambahkan sistem getaran lain (osilator) dengan massa $m_{d}$ dan konstanta pegas $k_{d}$ yang relatif lebih kecil dibandingkan dengan sistem utamanya. Jika frekuensi alami dari osilator itu, $\sqrt{ }\left(k_{d} / m_{d}\right)$, diatur sedemikian rupa sehingga sama dengan frekuensi getar dari gaya harmonis, maka dapat diperlihatkan secara teoritis bahwa massa utama menjadi tidak bergetar sama sekali. Pengaturan frekuensi osilator umumnya dilakukan dengan menyesuaikan massa osilator sehingga disebut tuned mass damper.

Gambar 1 mendeskripsikan sistem struktur - TMD secara skematis. Suatu struktur gedung dimodelkan sebagai sistem berderajat kebebasan tunggal dengan massa $\mathbf{M}_{1}$, konstanta redaman $\mathbf{C}_{1}$, dan konstanta pegas $\mathbf{K}_{1}$, yang masing-masing berarti massa, redaman, dan kekakuan yang berhubungan dengan ragam getar pertama dari gedung itu.

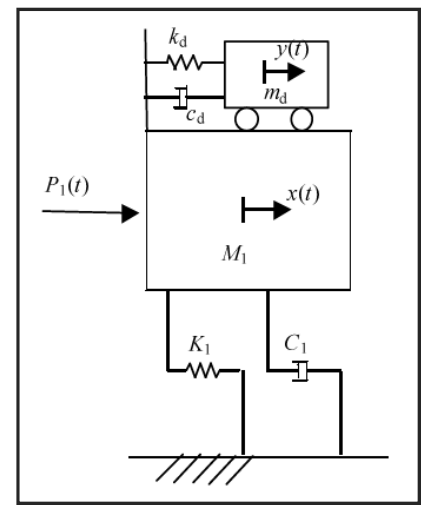

\section{Gambar 1. Sistem Struktur Bangunan TMD}

Agar respons sistem utama (struktur gedung) dapat diminimalkan, karakteristik osilator $c_{d}$ dan $k_{d}$ harus diatur besarnya sehingga optimum. Nilai-nilai optimum menurut Den Hartog adalah:

$$
\begin{aligned}
& r_{\text {opt }}=\frac{1}{\mu+1} \\
& \xi_{\text {opt }}=\sqrt{\frac{3 \mu}{8(\mu+1)}}
\end{aligned}
$$


dimana:

$$
\begin{array}{ll}
r_{\text {opt }} & =\text { rasio frekuensi optimum } \\
\xi_{\text {opt }} & =\text { rasio redaman optimum } \\
\mu & =\text { rasio antara massa } T M D \text { dengan massa total sistem utama }
\end{array}
$$

Dengan menggunakan persamaan di atas dapat ditentukan kekakuan dan redaman yang harus disediakan pada sistem $T M D$ bila rasio massa $m$, telah ditetapkan. Kekakuan dan redaman $T M D$ dapat dihitung dengan persamaan:

$\omega_{d}=r_{o p t} \omega$

$k_{d}=m_{d} \omega_{d}^{2}$

dimana :

$c_{d}=2 m_{d} \omega_{d} \xi_{\text {opt }}$

$\omega=$ frekuensi natural struktur utama

$\omega_{d}=$ frekuensi natural $T M D$

$m_{d}=$ massa $T M D$

$k_{d} \quad=$ kekakuan TMD

$c_{d} \quad=$ redaman $T M D$

\section{STUDI KASUS}

Studi kasus akan dilakukan terhadap satu jenis bangunan tinggi dengan layout bangunan berbentuk "U" dan dengan beberapa kasus yang berbeda, yaitu bangunan yang tidak menggunakan Tuned Mass Damper sama sekali (NTMD) dan bangunan yang menggunakan Tuned Mass Damper $(T M D)$. Digunakan tiga jenis $T M D$ dengan total rasio massa $1 \%, 2 \%$ dan 3\%, penggunaan $T M D$ dilakukan dengan 2 (dua) jenis yaitu Single TMD dan Multi TMD. Dari tiap kasus di atas akan diperoleh seberapa besar reduksi pengaruh beban gempa pada bangunan. Konfigurasi sistem strukturnya serta dimensi direncanakan sendiri dengan mengusahakan volume elemen struktur tambahan dari masing-masing tipe struktur sama atau hampir sama. Bentuk layout bangunan berbentuk "U", dengan deskripsi sebagai berikut :

1) Properti bangunan

Adapaun properti dari bangunan adalah jumlah lantai 40 lantai, tinggi tiap lantai $4 \mathrm{~m}$, luas per lantai $1080 \mathrm{~m}^{2}$, jarak antar kolom $6 \mathrm{~m}$, tebal lantai $12 \mathrm{~cm}$, fungsi bangunan untuk perkantoran. Mutu beton yang digunakan $35 \mathrm{MPa}$ dengan kondisi gempa pada wilayah zona 5 dan terletak di atas tanah sedang. Dimensi kolom lantai $1-20$ adalah $1000 \mathrm{~mm} \times 1000 \mathrm{~mm}$, lantai $21-40$ adalah $800 \mathrm{~mm} \times 800 \mathrm{~mm}$. Sedangkan dimensi balok untuk lantai $1-20$ adalah $800 \mathrm{~mm} \times 1200 \mathrm{~mm}$, lantai 21 - 39 adalah $600 \mathrm{~mm} \times 1200 \mathrm{~mm}$, lantai 40 adalah $400 \mathrm{~mm} \times 800 \mathrm{~mm}$. Konfigurasi dari sistem struktur tanpa $T M D$ dapat dilihat pada Gambar 2. Sedangkan konfigurasi dari sistem struktur dengan TMD dapat dilihat pada Gambar 3 untuk single TMD dan Gambar 4 untuk multi $T M D$.

\section{2) Properti Tuned Mass Damper}

Untuk Tuned Mass Damper, parameter massa $\left(m_{d}\right)$, kekakuan $\left(k_{d}\right)$ dan redaman $\left(c_{d}\right)$ dihitung menggunakan persamaan baku. Dalam hal ini akan direncanakan tiga macam jenis $T M D$ sesuai rasio massanya, yaitu $1 \%, 2 \%$ dan 3\%, dan penggunaan $T M D$ dilakukan dengan 2 (dua) jenis yaitu Single TMD dan Multi TMD yang ditempatkan di lantai puncak bangunan. Dari perhitungan, diperoleh massa total bangunan adalah $8,555597446 \times 10^{7} \mathrm{~kg}$. Setelah massa total struktur diketahui maka dengan demikian didapatkan nilai kekakuan struktur serta nilai frekuensi natural bangunan, dimana nilai kekakuan stuktur $2.09 \times 10^{5} \mathrm{~N} / \mathrm{mm}$ dan nilai dari frekuensi natural bangunan sebesar $4.94 \mathrm{~Hz}$ 

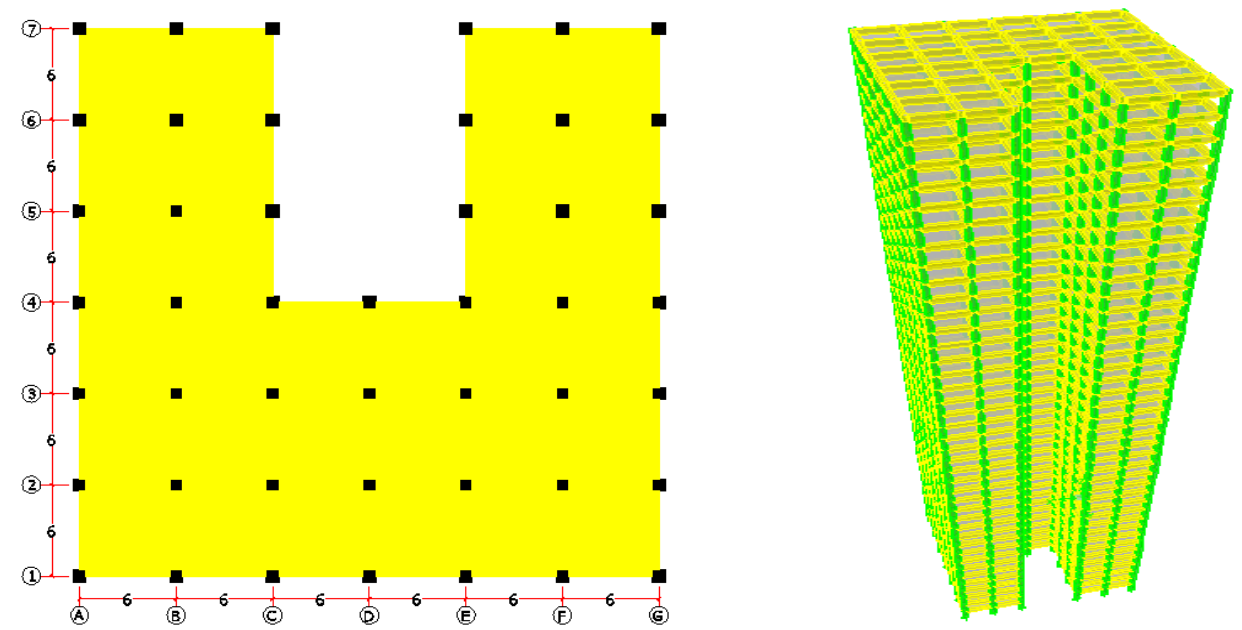

Gambar 2. Konfigurasi Sistem Struktur Gedung 40 Lantai NON TMD
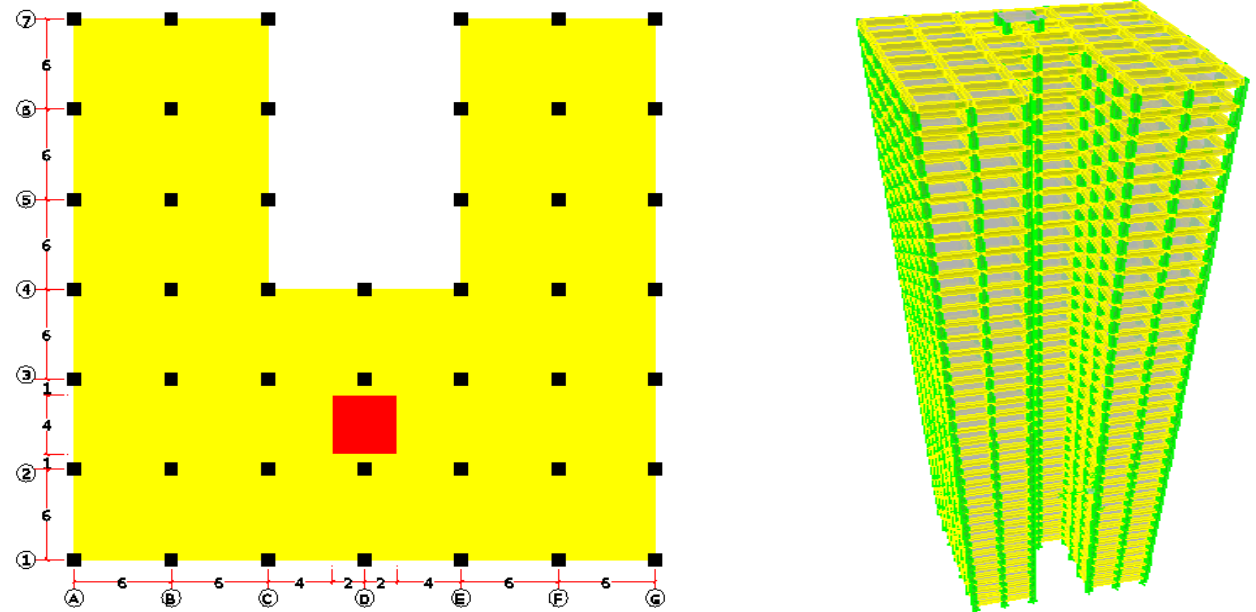

Gambar 3. Konfigurasi Sistem Struktur Gedung 40 Lantai SINGLE TMD
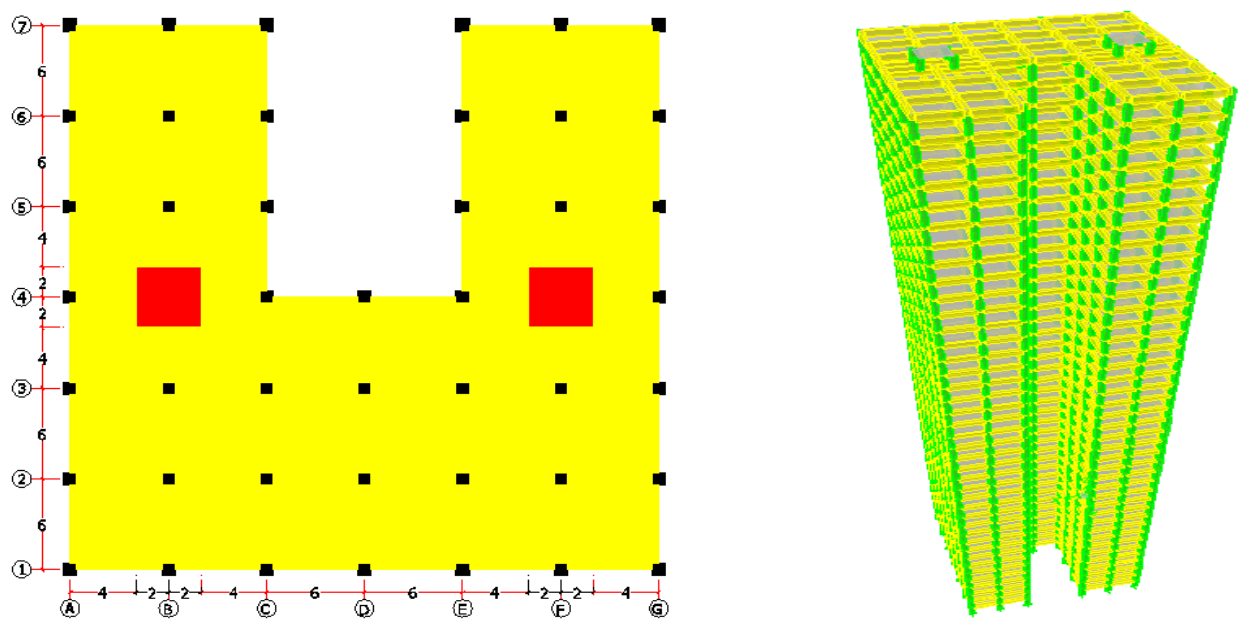

Gambar 4. Konfigurasi sistem struktur gedung 40 lantai TMD MULTI TMD 
4. HASIL

\subsection{Pengaruh Terhadap Gaya Dalam}

\subsubsection{Gaya Geser akibat Respon Spectrum Wilayah 5}

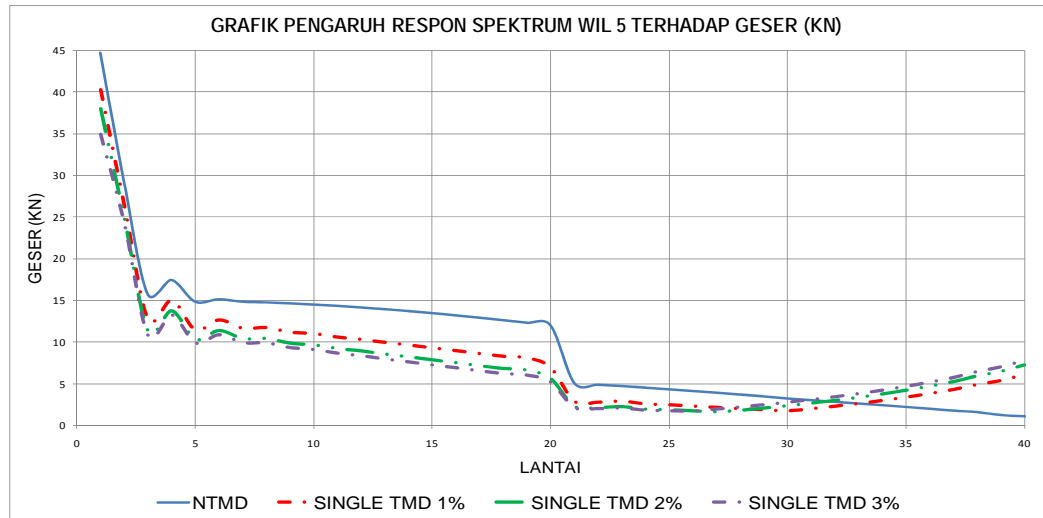

Grafik 1. Gaya Geser akibat Respon Spectrum Wilayah 5 (NTMD, SingleTMD 1\%, SingleTMD 2\%, SingleTMD 3\%)

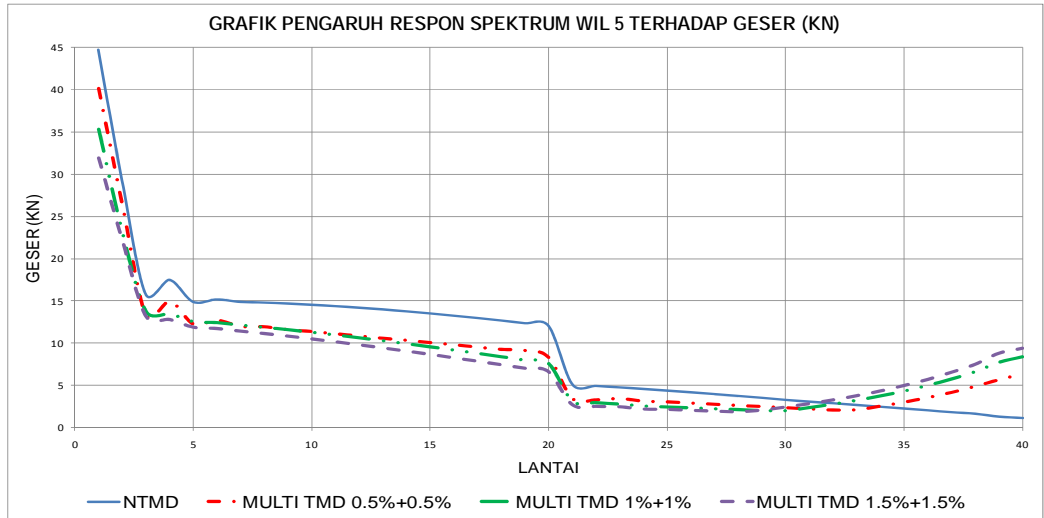

Grafik 2. Gaya Geser akibat Respon Spectrum Wilayah 5 (NTMD, MultiTMD 1\%, MultiTMD 1\%+1\%, MultiTMD 1.5\%+1.5\%)

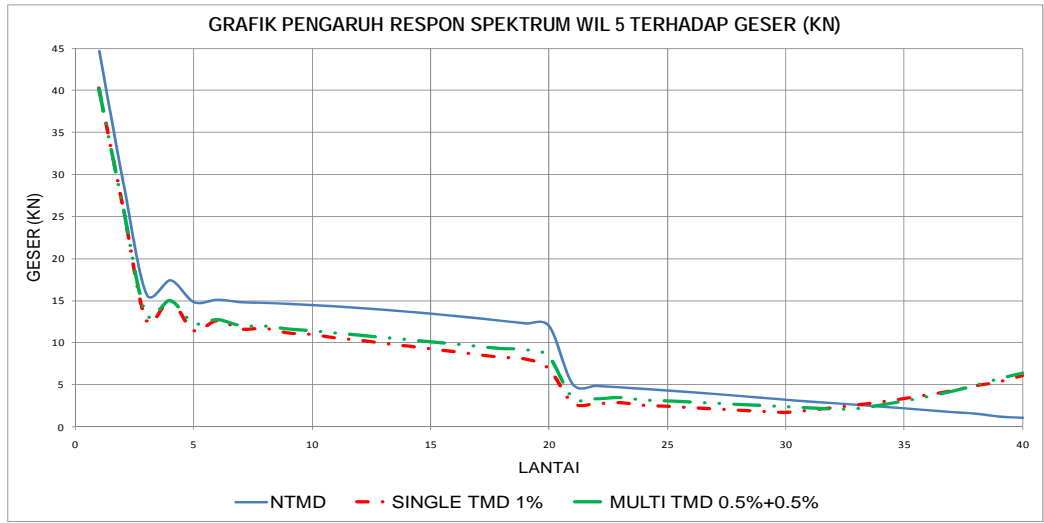

Grafik 3. Gaya Geser akibat Respon Spectrum Wilayah 5 (NTMD, SingleTMD 1\%, MultiTMD 0.5\%+0.5\%) 


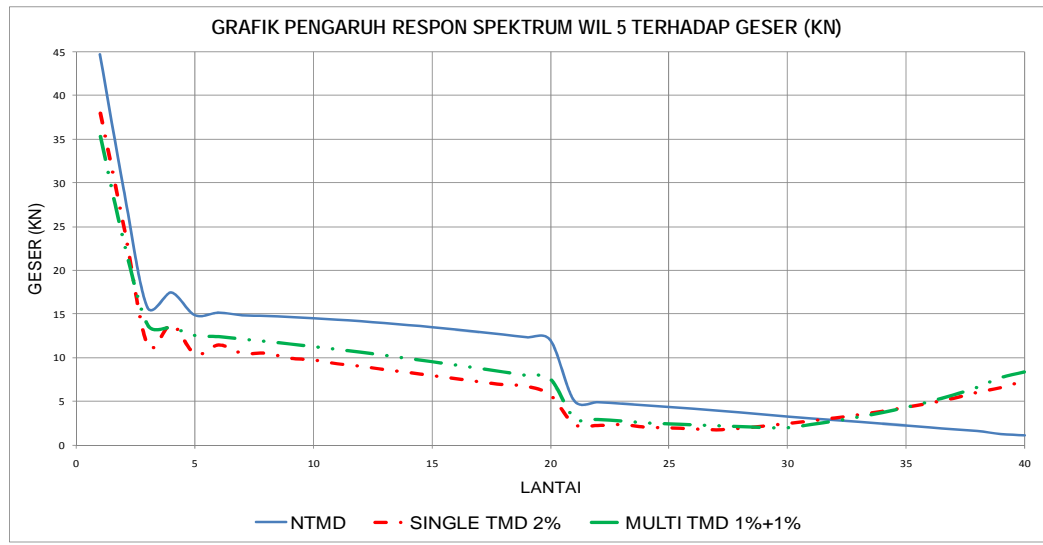

Grafik 4. Gaya Geser akibat Respon Spectrum Wilayah 5 (NTMD, SingleTMD 2\%, MultiTMD 1\%+ 1\%)

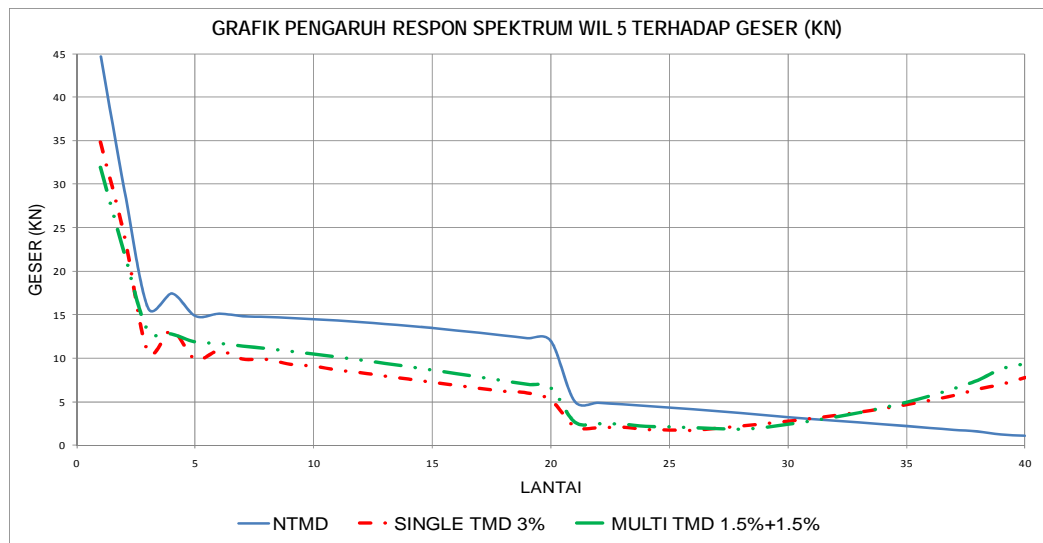

Grafik 5. Gaya Geser akibat Respon Spectrum Wilayah 5 (NTMD, SingleTMD 3\%, MultiTMD 1.5\%+1.5\%)

\subsubsection{Momen akibat Respon Spectrum Wilayah 5}

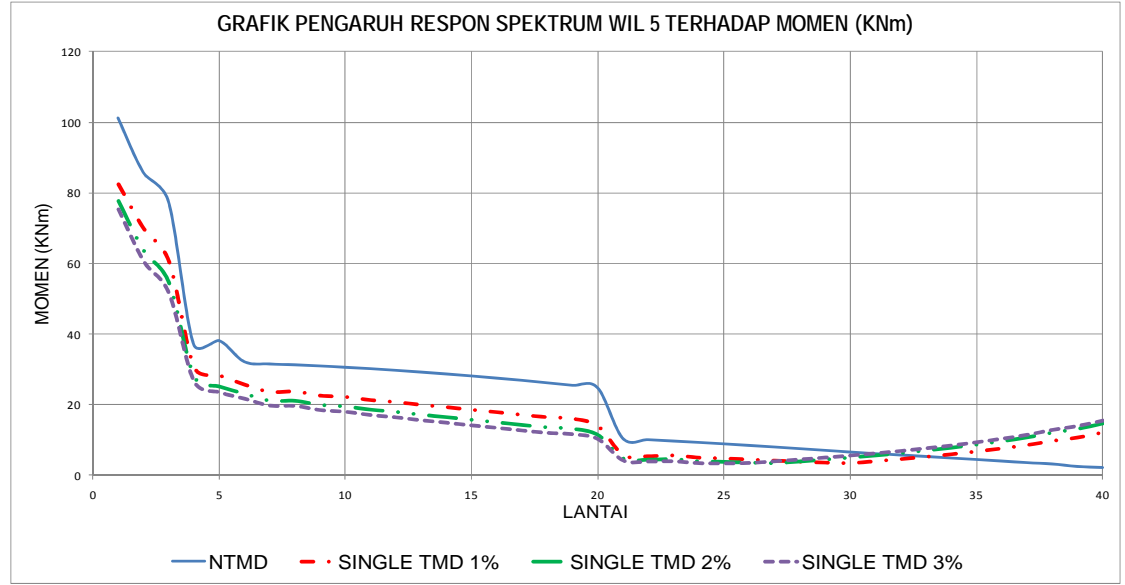

Grafik 6. Momen akibat Respon Spectrum Wilayah 5 (NTMD, SingleTMD 1\%, SingleTMD 2\%, SingleTMD 3\%) 


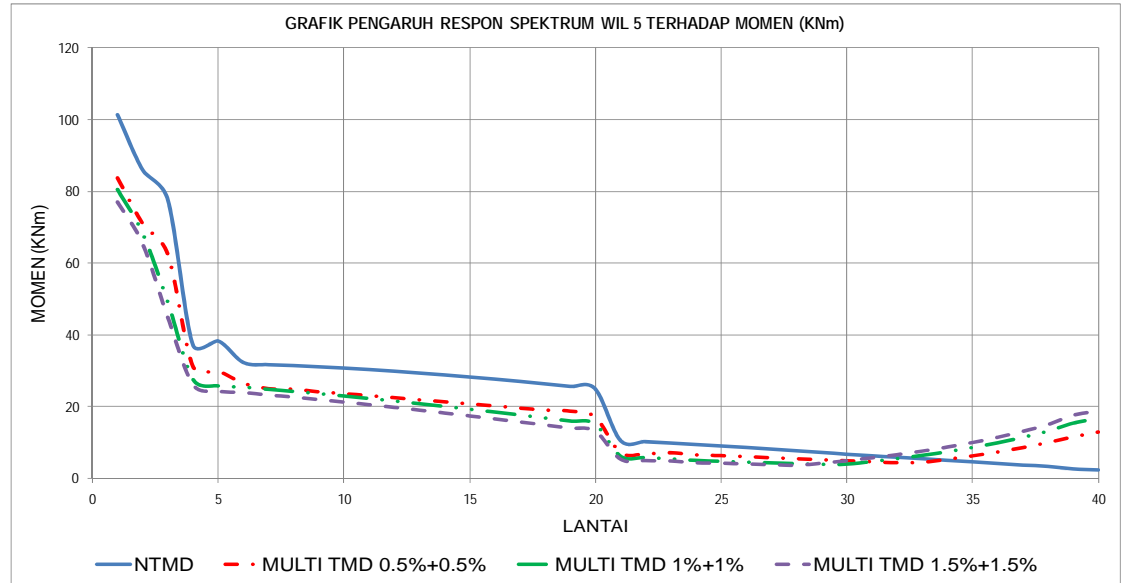

Grafik 7. Momen akibat Respon Spectrum Wilayah 5 (NTMD, MultiTMD 1\%, MultiTMD 1\%+1\%, MultiTMD 1.5\%+1.5\%)

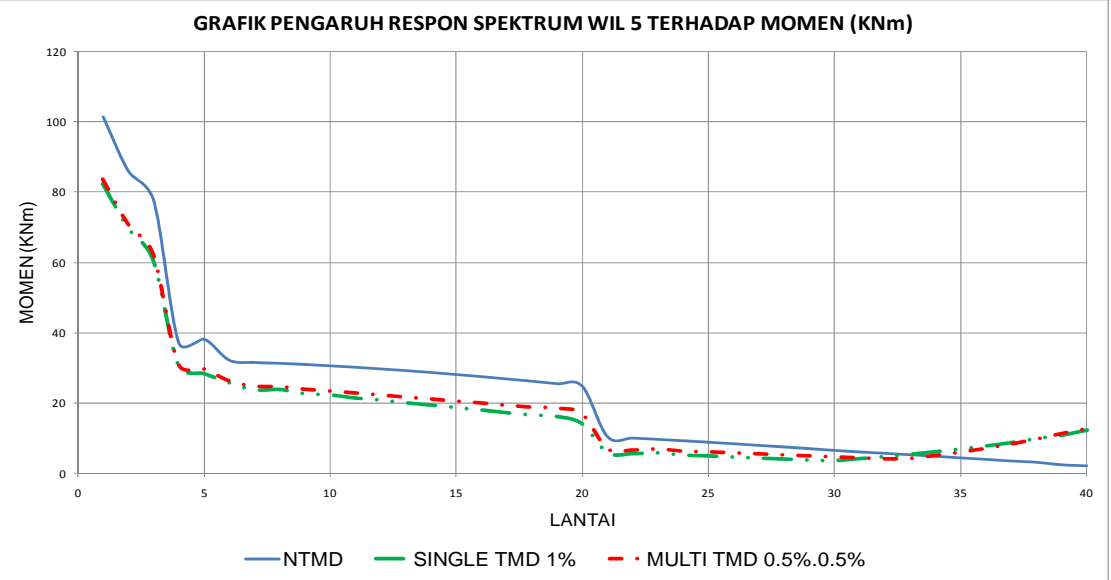

Grafik 8. Momen akibat Respon Spectrum Wilayah 5 (NTMD, SingleTMD 1\%, MultiTMD 0.5\%+0.5\%)

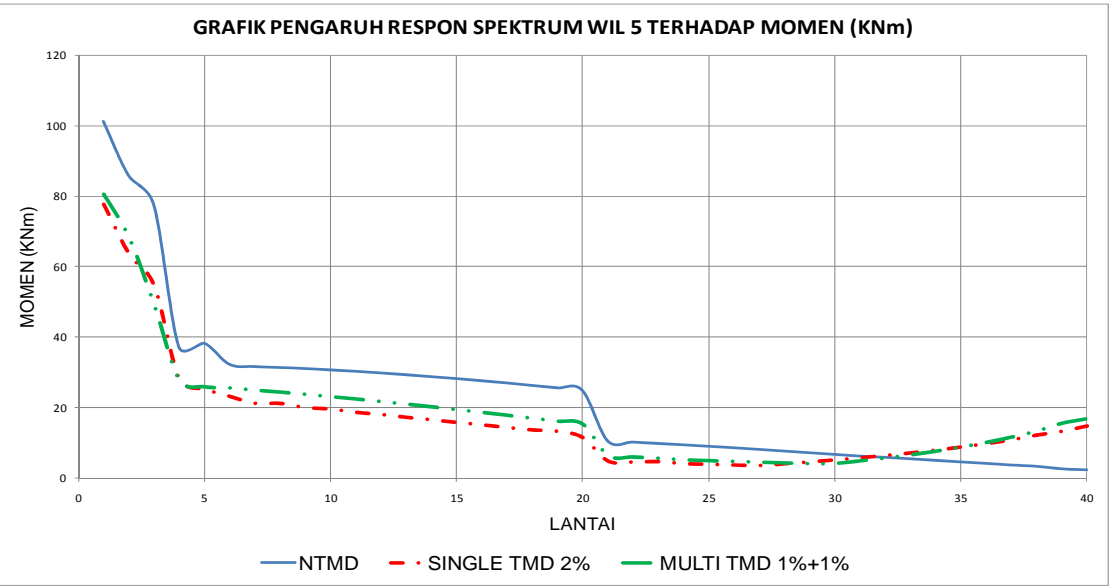

Grafik 9. Momen akibat Respon Spectrum Wilayah 5 (NTMD, SingleTMD 2\%, MultiTMD 1\%+1\%) 


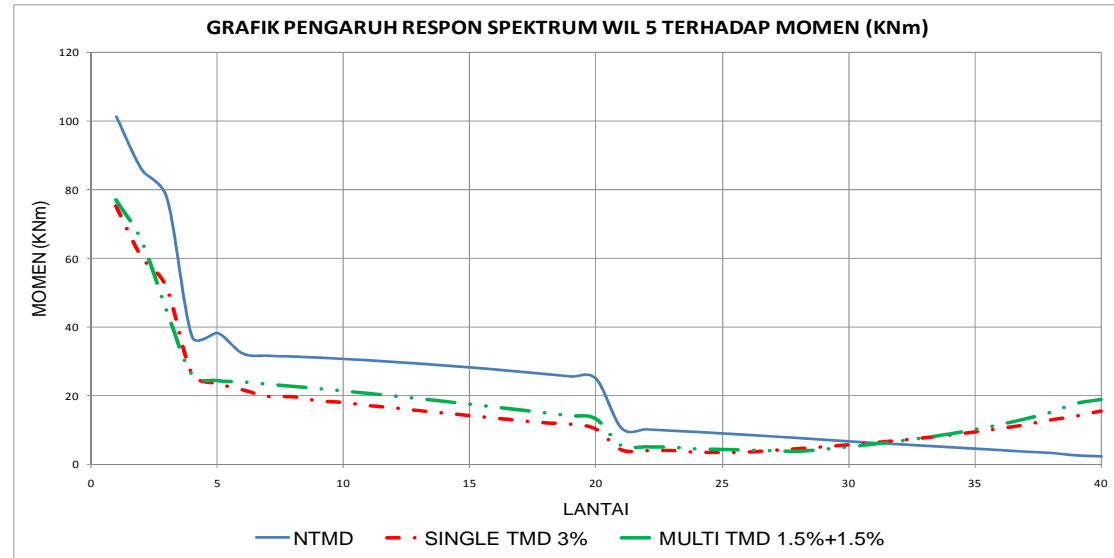

Grafik 10. Momen akibat Respon Spectrum Wilayah 5

(NTMD, SingleTMD 3\%, MultiTMD 1.5\%+1.5\%)

\subsection{Pengaruh Terhadap Deformasi}

\subsubsection{Deformasi Arah - X akibat Respon Spectrum wilayah 5}

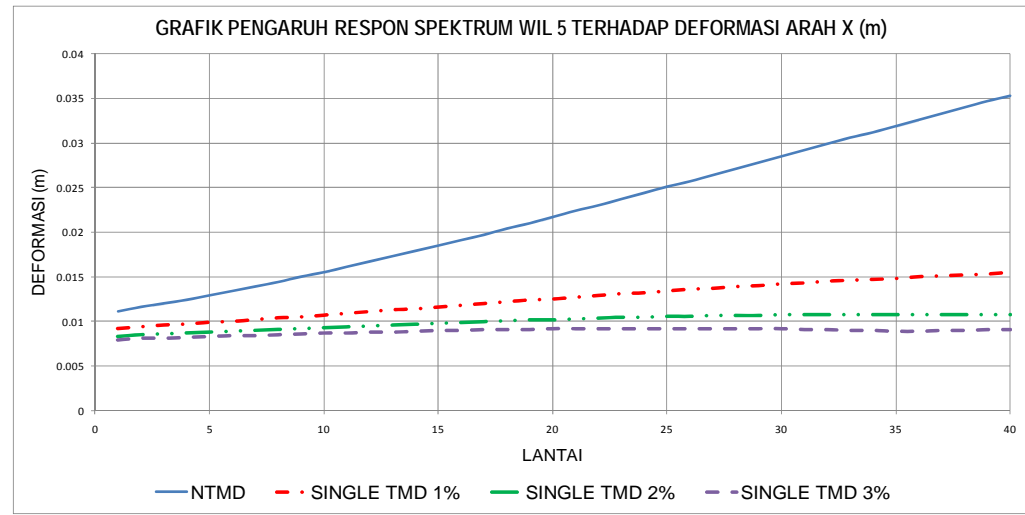

Grafik 11. Deformasi Arah - $X$ akibat Respon Spectrum Wilayah 5 (NTMD, SingleTMD 1\%, SingleTMD 2\%, SingleTMD 3\%)

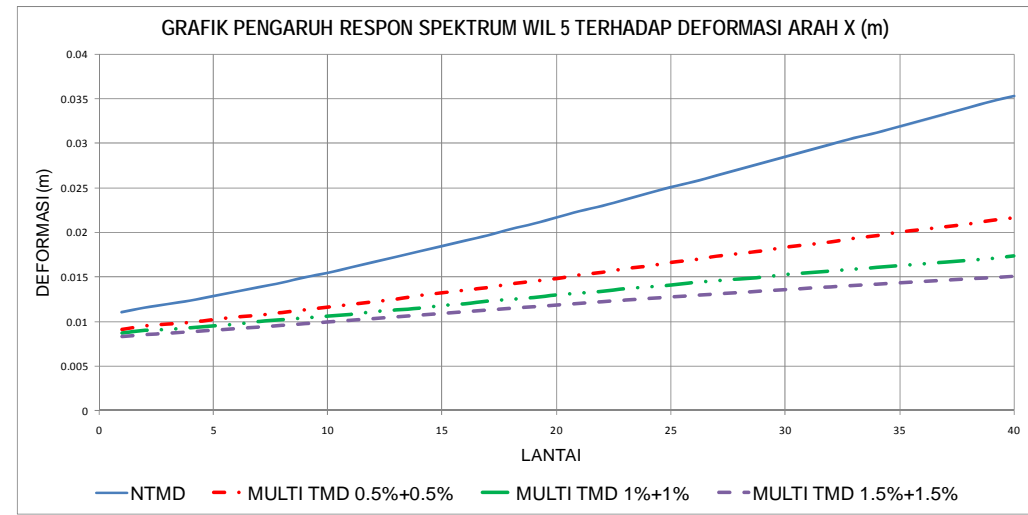

Grafik 12. Deformasi Arah - $X$ akibat Respon Spectrum Wilayah 5 (NTMD, MultiTMD 1\%, MultiTMD 1\%+1\%, MultiTMD 1.5\%+1.5\%) 


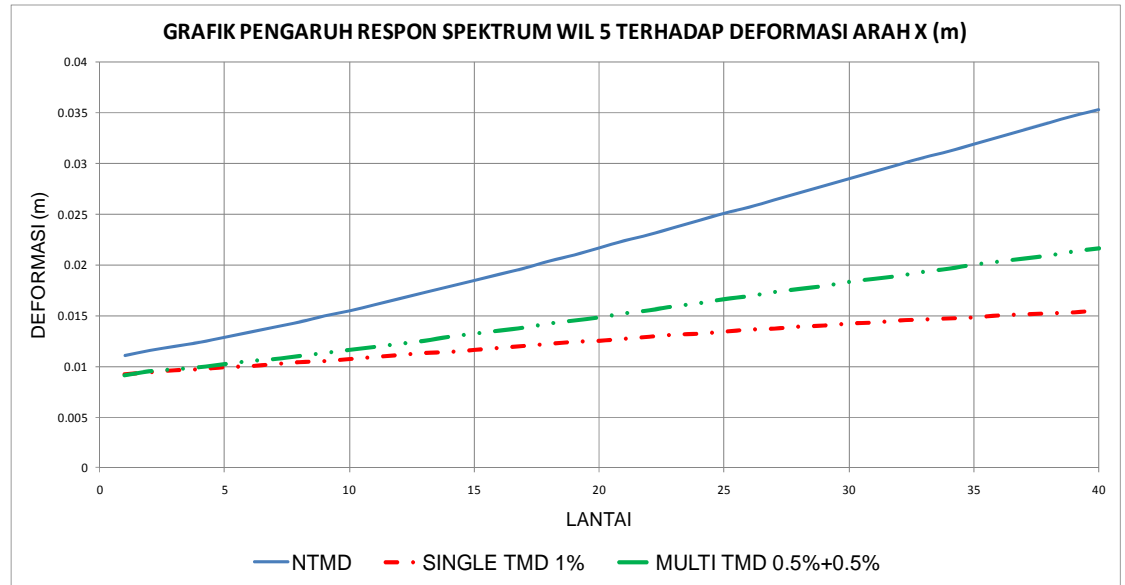

Grafik 13. Deformasi Arah - $X$ akibat Respon Spectrum Wilayah 5 (NTMD, SingleTMD 1\%, MultiTMD 0.5\%+0.5\%)

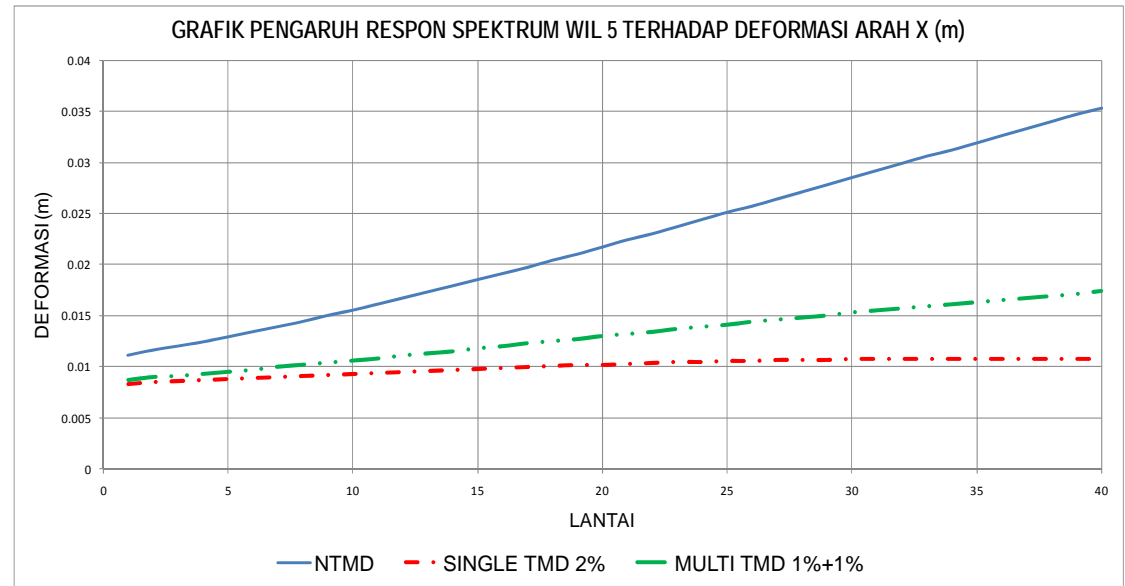

Grafik 14. Deformasi Arah - $X$ akibat Respon Spectrum Wilayah 5 (NTMD, SingleTMD 2\%, MultiTMD 1\%+1\%)

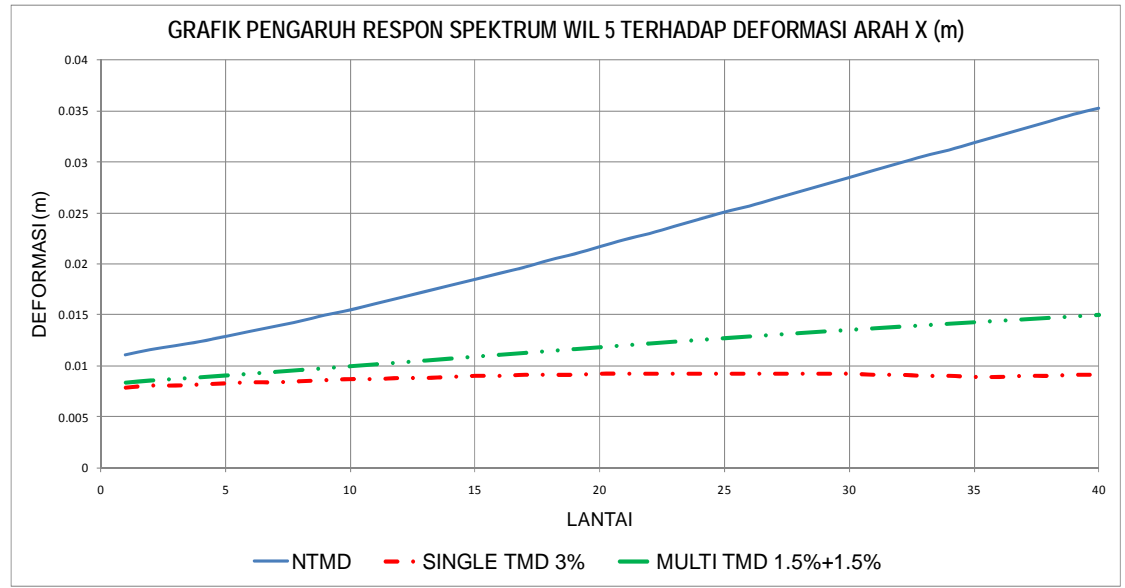

Grafik 15. Deformasi Arah - $X$ akibat Respon Spectrum Wilayah 5 (NTMD, SingleTMD 3\%, MultiTMD 1.5\%+1.5\%) 


\subsubsection{Deformasi Arah - Y akibat Respon Spectrum Wilavah 5}

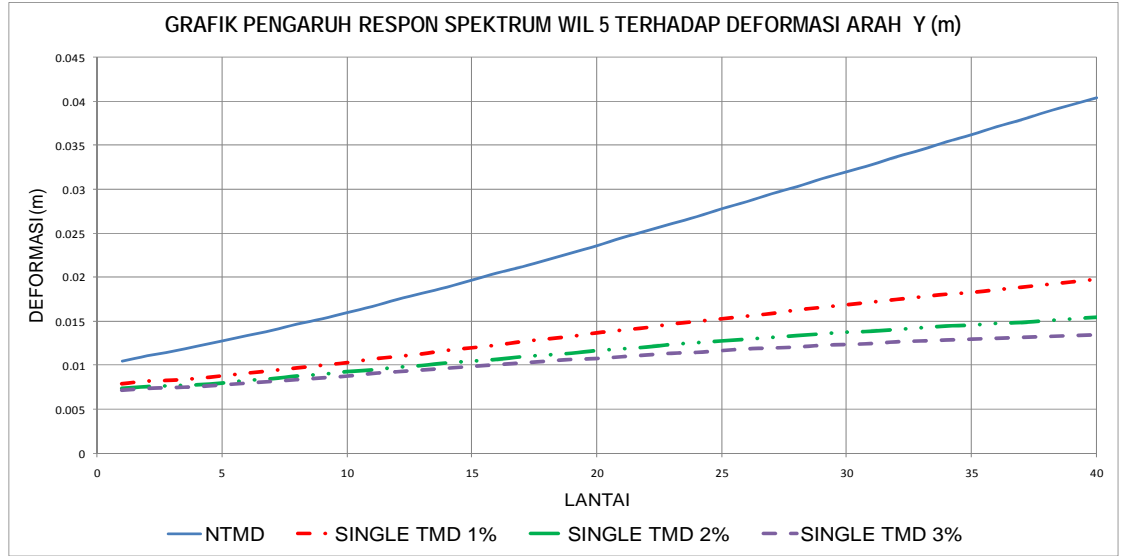

Grafik 16. Deformasi Arah - $Y$ akibat Respon Spectrum Wilayah 5 (NTMD, SingleTMD 1\%, SingleTMD 2\%, SingleTMD 3\%)

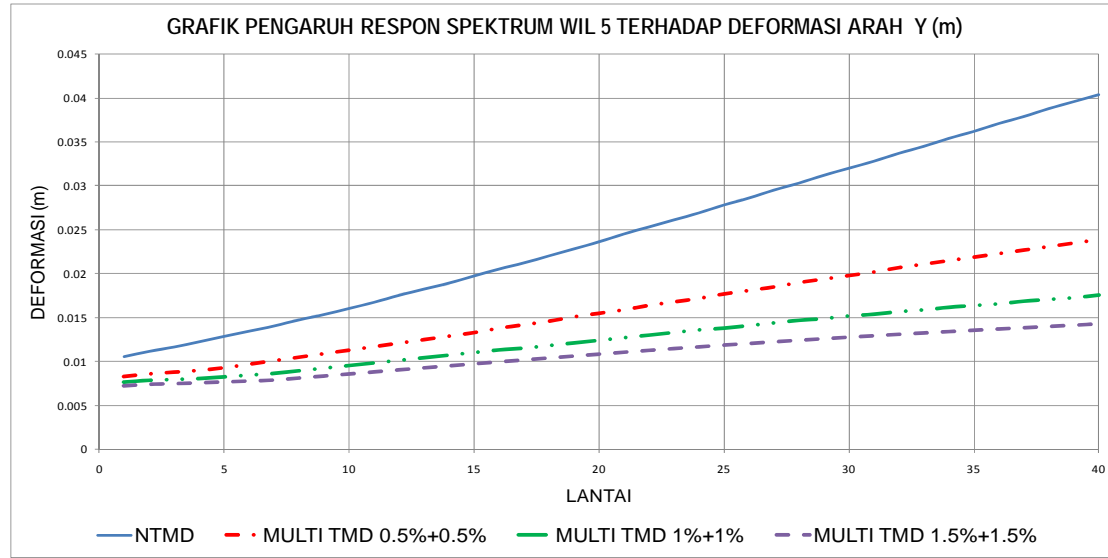

Grafik 17. Deformasi Arah - $Y$ akibat Respon Spectrum Wilayah 5 (NTMD, MultiTMD 1\%, MultiTMD 1\%+1\%, MultiTMD 1.5\%+1.5\%)

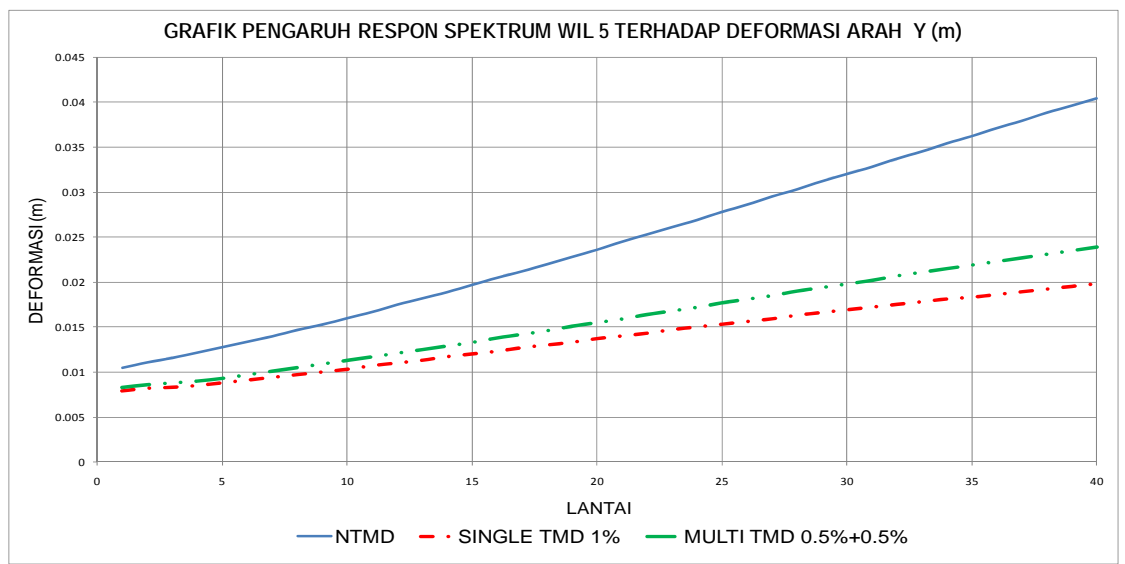

Grafik 18. Deformasi Arah - $Y$ akibat Respon Spectrum Wilayah 5 (NTMD, SingleTMD 1\%, MultiTMD 0.5\%+0.5\%) 


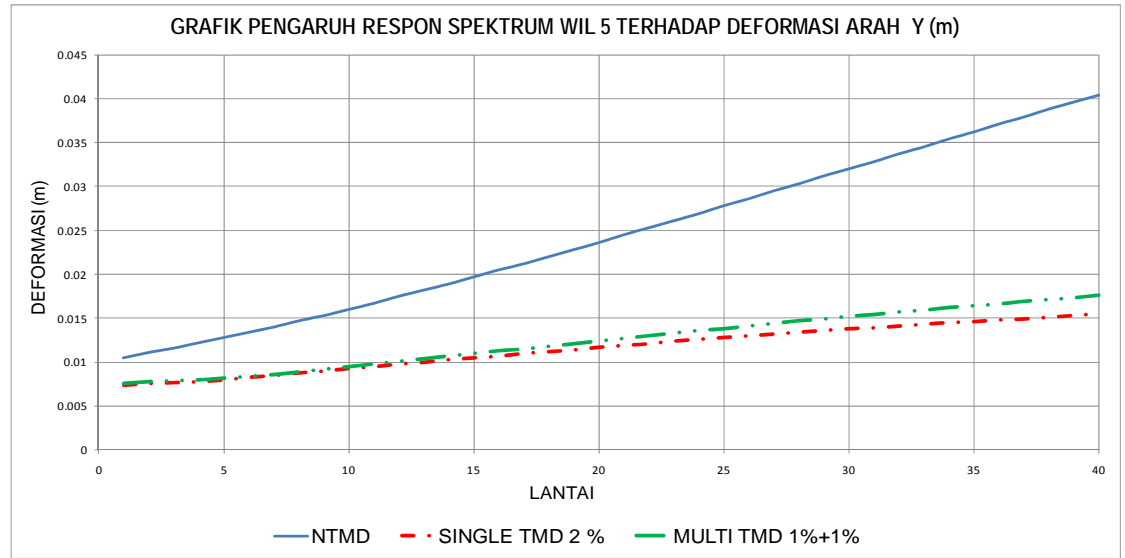

Grafik 19. Deformasi Arah - $Y$ akibat Respon Spectrum Wilayah 5 (NTMD, SingleTMD 2\%, MultiTMD 1\%+1\%)

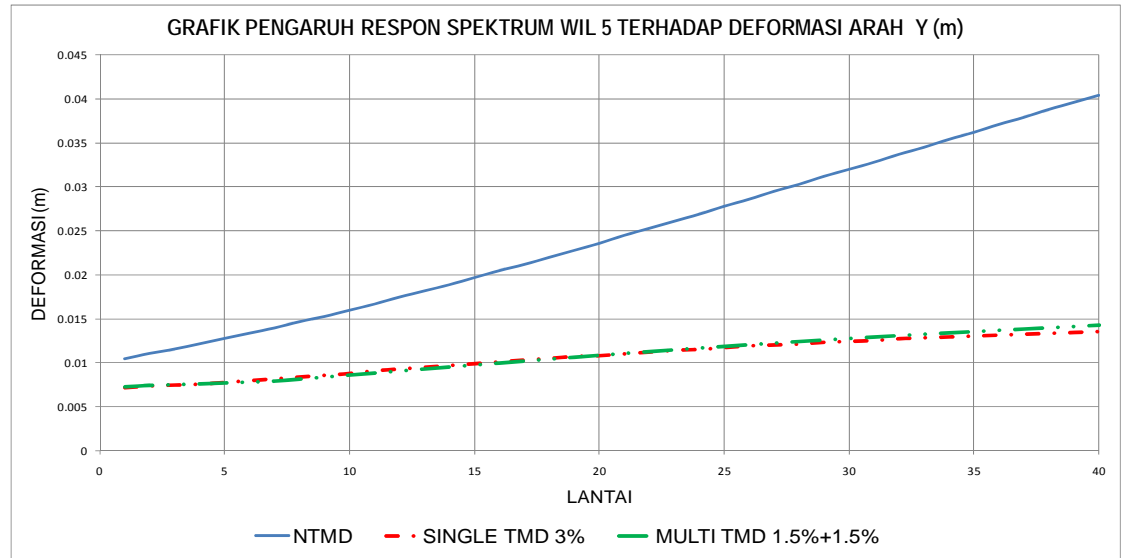

Grafik 20. Deformasi Arah - $Y$ akibat Respon Spectrum Wilayah 5 (NTMD, SingleTMD 3\%, MultiTMD 1.5\%+1.5\%)

\subsection{Perioda}

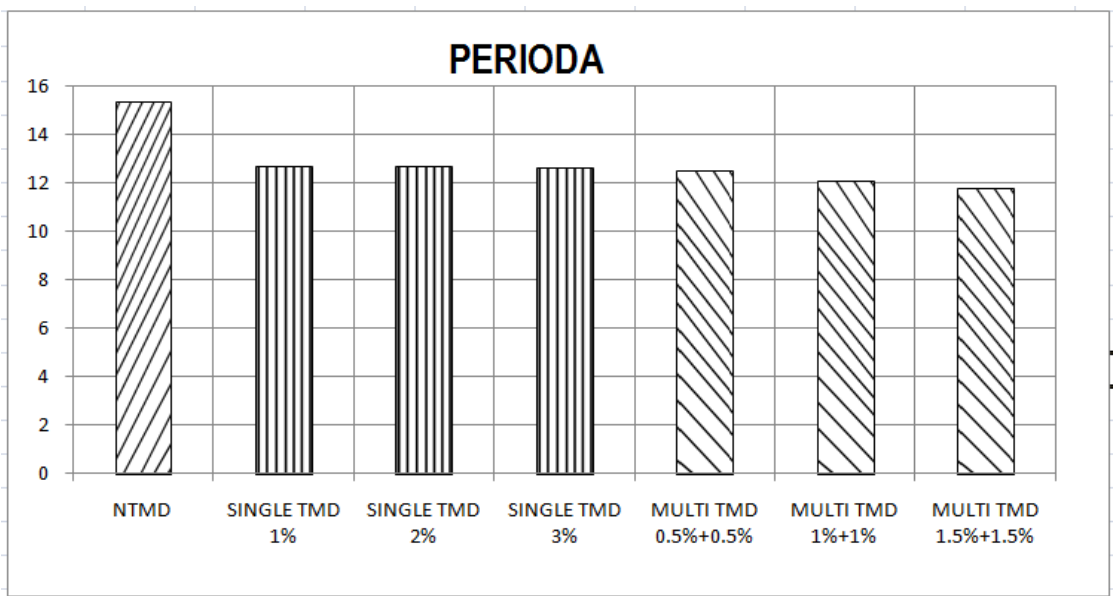

Grafik 21. Perbandingan Perioda Beberapa Jenis TMD 


\section{ANALISA DAN PEMBAHASAN}

Gaya dalam yang terjadi akan dipengaruhi oleh beban-beban yang bekerja pada bangunan, baik itu disebabkan oleh beban sendiri, maupun beban luar seperti beban manusia, angin, gempa dan lainlain. Selain itu, penambahan beban Tuned Mass Damper (TMD) sebagai tujuan untuk mereduksi deformasi maksimum bangunan juga akan mempengaruhi gaya-gaya dalam. Dalam penelitian ini akan diperlihatkan pengaruh dari penggunaan $T M D$ berdasarkan tingkat rasio massa $T M D$ terhadap bangunan. Dalam hal ini, TMD yang diuji memiliki variasi dengan rasio massa $1 \%, 2 \%, 3 \%$. Jenis $T M D$ antara lain tidak menggunakan TMD (NTMD), singleTMD dan multiTMD. Untuk lebih memperakurat data, beban dinamis yang digunakan adalah beban dari respon spectrum wilayah 5 . Dari jenis beban ini akan terlihat jelas pengaruh penggunaan TMD terhadap gaya dalam.

\section{Pengaruh TMD terhadap Gaya Dalam}

Pada Grafik 1 sampai Grafik 10, terlihat pengaruh penggunaan $T M D$ terhadap gaya geser dan gaya momen yang terjadi. Dari grafik tersebut terlihat rata-rata kurva bangunan yang tidak memakai Tuned Mass Damper (NTMD) berada di posisi paling atas dari bangunan yang memakai $T M D$. Selanjutnya juga terlihat bangunan menggunakan $T M D$ dengan rasio massa $1 \%$ berada di atas $T M D$ dengan rasio massa $2 \%$ dan 3\%, sementara TMD dengan rasio 3\% berada di posisi paling bawah. Pada jenis beban dinamis yang digunakan (beban gempa wilayah 5), selalu terlihat urutan kurva mulai paling atas hingga paling bawah dimulai dari NTMD, TMD 1\%, TMD 2\% hingga TMD $3 \%$ baik pada singleTMD maupun multiTMD. Pada Grafik 5 dan Grafik10, juga dapat dibandingkan, bahwa penggunaan singleTMD lebih efektif dari penggunaan multiTMD. Dapat dilihat bahwa grafik singleTMD berada di bawah multiTMD. Adanya TMD pada puncak bangunan juga mengakibatkan naiknya nilai gaya dalam pada beberapa lantai teratas, hal ini dikarenakan beban TMD itu sendiri.

Dari analisa grafik di atas, dapat disimpulkan bahwa semakin besar beban TMD yang digunakan, maka gaya dalam struktur yang dihasilkan akan semakin kecil (gaya dalam berkurang). Penggunaan TMD untuk bangunan gedung tinggi dengan layout bangunan berbentuk "U" lebih efektif. Hal ini terjadi karena cara kerja TMD yang terjadi ketika bangunan berdeformasi horizontal, TMD akan bergerak berlawanan arah dari deformasi horizontal bangunan sehingga mengurangi dampak dari beban horizontal yang bekerja pada bangunan. Karena pengurangan nilai beban horizontal inilah akan menyebabkan gaya dalam pada bangunan juga berkurang.

\section{Pengaruh TMD terhadap Deformasi}

Pada Grafik 11 dan Grafik 15, terlihat bentuk grafis dari pengaruh deformasi arah - $x$ akibat variasi berat $T M D$ yang bekerja. Kurva $N T M D$ berada di urutan paling atas, selanjutnya kurva SingleTMD 1\%, 2\%, dan yang paling bawah adalah kurva singleTMD 3\%. Dilihat dari grafik akibat beban respon spectrum wilayah 5, dan arah - $y$ pada Grafik 16 dan Grafik 20, semuanya memiliki posisi kurva yang sama seperti urutan di atas, Kurva NTMD berada di urutan paling atas, selanjutnya kurva MultiTMD 1\%, 2\%, dan yang paling bawah adalah kurva MultiTMD 3\%. Pada Grafik 15 dan Grafik 20, juga dapat dibandingkan bahwa penggunaan singleTMD lebih efektif dari penggunaan multiTMD. Dapat dilihat bahwa grafik singleTMD berada di bawah multiTMD (nilai deformasi terkecil).

Dari analisa grafik di atas, dapat dikatakan bahwa semakin besar nilai berat dari $T M D$, maka deformasi horizontal bangunan yang terjadi akibat beban dinamis akan semakin berkurang. Maka dapat disimpulkan bahwa penggunaan TMD menguntungkan dalam mereduksi goyangan horizontal akibat beban gempa.

\section{Pengaruh TMD terhadap Perioda}

Pada Grafik 21, terlihat bentuk grafik pengaruh penggunaan $T M D$ terhadap perioda. Grafik semakin turun dari NTMD, TMD 1\%, TMD 2\%, dan yang paling rendah TMD 3\%. Perioda 
multiTMD lebih kecil dari pada singleTMD. Perioda pada struktur yang menggunakan Multi TMD dengan massa $1.5 \%+1.5 \%$ dari total massa struktur memiliki perioda getar paling kecil, yaitu 11,78 detik dan perioda getar terbesar pada $N T M D$, yaitu 15,344585 detik.

\section{KESIMPULAN}

Adapun faktor-faktor yang mempengaruhi perilaku struktur yang menggunakan $T M D$ adalah penempatan $T M D$, persentase massa $T M D$, jumlah $T M D$ yang ditempatkan pada struktur.

1. Secara umum $T M D$ mampu mereduksi respon struktur seperti deformasi dan gaya dalam (gaya geser dan momen).

2. Pada penggunaan Single $T M D$, semakin besar massa $T M D$ tersebut maka akan semakin mereduksi respon struktur yang terjadi.

3. Pada penggunaan Multi TMD, semakin besar massa TMD tersebut maka akan semakin mereduksi respon struktur yang terjadi.

4. Dari hasil analisa yang telah dilakukan untuk struktur bangunan tinggi dengan layout berbentuk "U", diperoleh bahwa penggunaan SingleTMD dengan persentase massa TMD 3\% dapat mewakili setiap penempatan $T M D$ yang dicoba karena nilai respon struktur yang dihasilkan lebih kecil dari pada yang lainnya.

5. Nilai reduksi respon struktur rata-rata yang dihasilkan oleh SingleTMD 3\% terhadap NTMD (dalam \%) adalah pada gaya geser $(27,43 \%)$, momen $(31,33 \%)$, deformasi arah sumbu $\mathrm{x}$ $(60,43 \%)$ dan deformasi arah sumbu y $(50,46 \%)$.

\section{DAFTAR PUSTAKA}

Kurniawan, Ihsan, (2009), Studi Efektifitas Penggunaan Tuned Mass Damper untuk Mengurangi Pengaruh Beban Dinamik Pada Struktur Bangunan Tinggi, Universitas Andalas, Padang.

Takenaka Corporation, (2001), Structural Control System, http://www.takenaka.co.jp/takenaka e/ quake e/seishin/seishin.htm (29 Jan. 2003).

Chopra, Anil K., (1995), Dynamics of Structures: Theory and Applications to Earthquake Engineering, Prentice Hall, New Jersey, pp. 432-433.

McNamara, Robert J., Tuned mass damper for Buildings, Journal of Structural Division, ASCE, Vol.103.

Ogata, Katsuhiko, (1994), Teknik Kontrol Automatik (Sistem Pengaturan), Jilid 2, Cetakan Keempat, Erlangga, Jakarta.

Soong, T.T., (1990), Active Structural Control: Theory and Practice, Longman Scientific and Technical, Harlow, pp. 7-10, 177-183.

Schueller, Wolfgang, (1990), The Vertical Building Structure, Van Nostrand Reinhold Company, New York, page 531. 
Studi Efektifitas Penggunaan Tuned Mass Damper untuk Mengurangi Pengaruh Beban Gempa pada Struktur Bangunan Tinggi dengan Layout Bangunan Berbentuk " $U$ "

\section{6 | JURNAL REKAYASA SIPIL}

